\title{
The Role of the Far East in Russia's Foreign Energy Policy Agenda
}

\author{
Olga Dyomina ${ }^{1, *}$ \\ ${ }^{1}$ Candidate of Sciences (Economics), Senior Research Fellow, Economic Research Institute of Far Eastern Branch of the Russian \\ Academy of Sciences, 153 Tikhookeanskaya Street, Khabarovsk, Russia, 680042
}

\begin{abstract}
The evolution of goals and objectives of the Energy Strategy of Russia for the period from 2003 to 2020 is considered. It is shown that the main priority of the foreign energy policy is to maintain and strengthen the country's position in the world markets. It is determined that the country is actually consolidating the strategy of increasing production with the subsequent export of hydrocarbon raw materials. It is noted that the target indicators of the strategy, along with the share of Asia-Pacific countries in the geographical structure of Russian energy exports, is an increase in the share of primary energy production in Eastern Siberia and the Far East. The role of the Far East in Russia's foreign energy policy agenda is analyzed. It is determined that the Far East acts as a transit territory and as a hydrocarbon and coal resource base. The development of the fuel and energy complex in the region is carried out within the framework of large energy projects in four categories: the Eastern Siberia - Pacific Ocean oil pipeline (ESPO) and the development of fields along the pipeline route; a set of interrelated projects within the Eastern Gas Program; development of the coal industry and related rail and port infrastructure; cross-border electricity exports to China
\end{abstract}

The main document defining the priorities and directions of development of the fuel and energy complex (FEC) of Russia is the Energy Strategy, according to the latest version, focused until 2035 . According to the developers, this document should ensure the integrity of the state energy policy by setting top-level goals, which are disclosed in a system of interrelated "industry and regional strategic documents (General Schemes and state programs) that specify the provisions of the Strategy and link them to the investment plans of companies" [1]. The place of the Energy Strategy of Russia until 2035 in the system of basic documents determining the development of the fuel and energy complex is shown in Figure 1.

Russia is one of the leading players in the world energy markets, so one of the main priorities of the foreign energy policy is to maintain and strengthen the country's position in the world markets. A retrospective analysis of the main directions of the country's foreign energy policy shows that this goal has remained unchanged over the past three decades (Table 1).

In order to achieve this goal (in terms of maintaining the current market niches in the energy markets), the need for diversification of directions is postulated supply and expansion of the range of products of the fuel and energy complex with an increase in the share of products with high added value. Russia is still holding the global leadership in the field of coal and hydrocarbon production, while it is still lagging behind the main players in the global hydrocarbon market in the field of refining. We are talking about the lack of transition to products of a higher level of processing, which does not contribute to the formation of new product niches with Russian fuel and energy products. The country is actually consolidating the strategy of increasing production with the subsequent export of hydrocarbon raw materials [3].

Increased interest in the development of the fuel and energy sectors of the Far East has been observed since the early 2000s. For the entire period up to 2020, one of the external priorities of the Energy Development Strategy is declared to be the diversification of export directions, which implies increasing the presence of Russian energy resources in the markets of the AsiaPacific countries. The achievement of this goal is associated with the increased development of the fuel and energy sectors of Eastern Siberia and the Far East. To date, this direction of development of the fuel and energy sector remains not only relevant, but also has significantly increased its priority within the framework of the Energy Strategy of Russia until 2035.

That is why one of the target indicators of the strategy, along with the share of Asia-Pacific countries in the geographical structure of Russian energy exports, is an increase in the share of primary energy production in Eastern Siberia and the Far East (Table 2).

The role of the Far East is determined, firstly, by the large-scale development of new energy resources, and, secondly, by the use of the territory for the transit of.

* Corresponding author: demina@ecrin.ru 


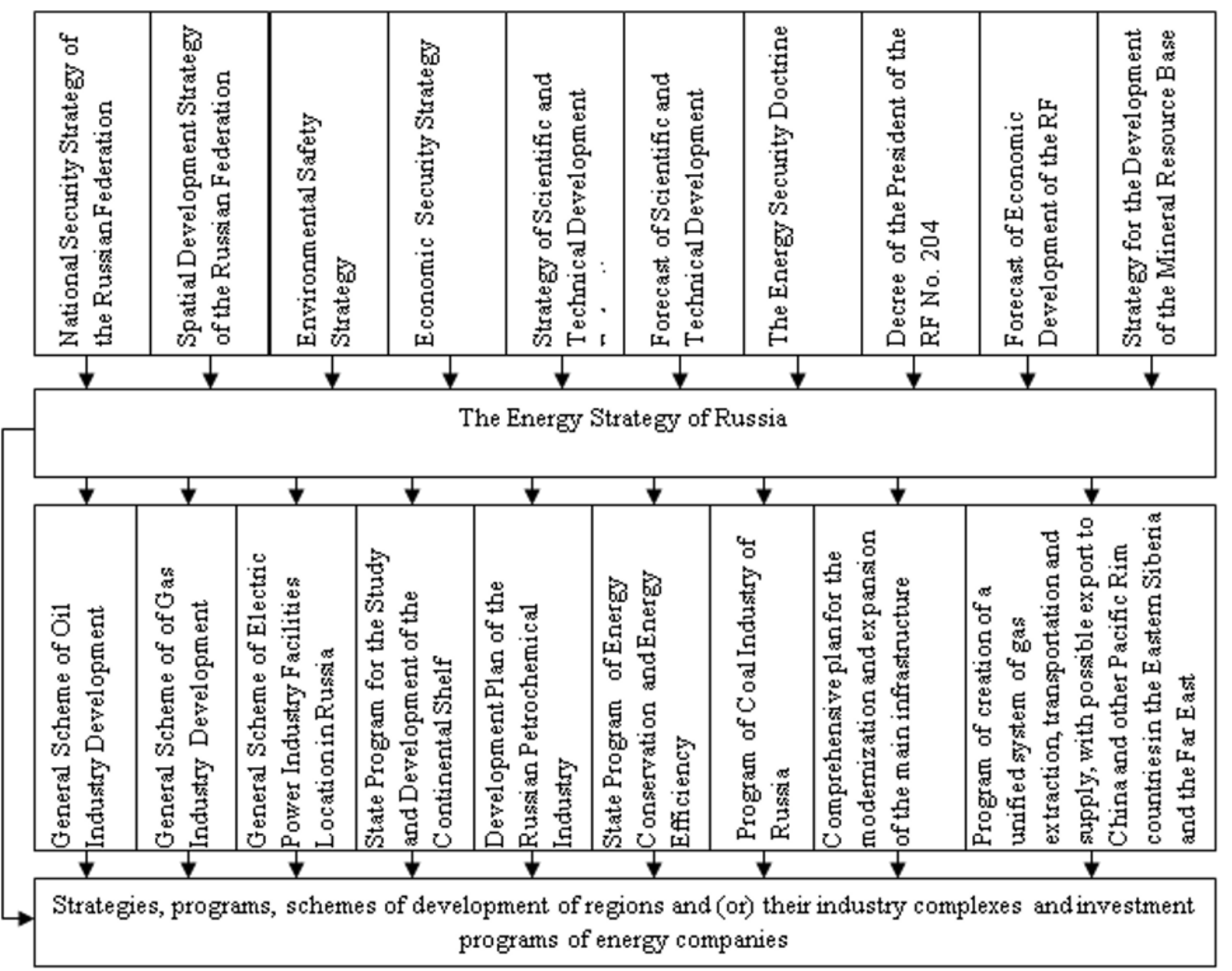

.Fig. 1 The place of the Energy Strategy of Russia until 2035 in the system of basic documents

energy resources from the regions of Siberia [8]. The development of the region's fuel and energy sectors was supposed to be part of the implementation of major energy projects.

The idea of Russian energy resources entering the dynamic and large-scale markets of the Asia-Pacific countries has almost a thirty-year history, since the early 1990s, when projects for the export of Russian gas, oil and electricity to China were discussed $[7 ; 9 ; 10]$. They have become prototypes of the projects that are considered within the framework of the strategy (Table 3). In a generalized form, they can be divided into four categories: the Eastern Siberia-Pacific Ocean oil pipeline and development of fields along the pipeline route; a set of interrelated projects under the Eastern Gas Programa; development of the coal industry and related railway and port infrastructure; cross-border electricity exports to China.

\footnotetext{
a Program of creation of a unified system of gas extraction, transportation and supply, with possible export to China and other Pacific Rim countries in the Eastern Siberia and the Far East, adopted by the of the Ministry of Industry and Energy of the Russian Federation
}

All the projects are highly capital-intensive and assume a primary focus on external demand, since the capacity of the domestic market for their operation is not enough. Accordingly, their implementation requires compliance with certain conditions: a guaranteed longterm sales market, leveling of transit risks, access to financial resources and technologies. These conditions were provided only for individual projects, primarily in the oil and coal industry, partly in the gas and electric power industry.

The actual contribution of these projects to the development of the economy of the territories of the Far East was more modest than the initially expected effects. However, from the point of view of defending Russia's geopolitical interests, it can be noted that projects in the oil industry were implemented in a timely manner and allowed Russian energy resources to occupy stable niches in the most promising markets of the Asia-Pacific region (China, Japan, the Republic of Korea). Projects in the coal industry have developed rapidly in response to the high growth rate of demand for imported products in China, Japan, and the Republic of Korea [2]. In terms of projects in the gas industry, there is a delay in the deadlines. Since the most favorable time was lost, their implementation is carried out in the conditions of unfavorable market conditions and increased competition of suppliers in the Asia-Pacific markets. In the electric power industry, only the projects for the 
development of cross-border electricity trade between Russia and China have been developed, and the largescale export project has not been implemented due to the high capital intensity and high risks for the Russian side [4].

Table 1. The evolution of goals in relation to foreign energy policy.

\begin{tabular}{|c|c|}
\hline Energy strategy & Foreign energy policy goals \\
\hline $\begin{array}{l}\text { Energy strategy - } \\
2020^{\mathrm{b}}\end{array}$ & 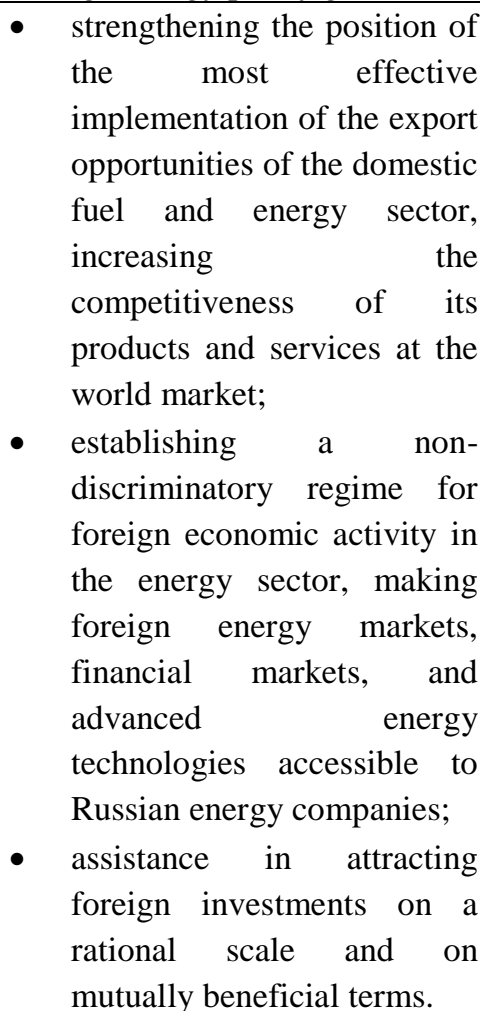 \\
\hline $\begin{array}{l}\text { Energy strategy - } \\
2030^{c}\end{array}$ & $\begin{array}{l}\text { - the most effective use of } \\
\text { Russia's energy potential for } \\
\text { full integration into the } \\
\text { global energy market, } \\
\text { strengthening its position in } \\
\text { it and obtaining the greatest } \\
\text { benefits for the national } \\
\text { economy. }\end{array}$ \\
\hline $\begin{array}{l}\text { Energy strategy - } \\
2035^{\mathrm{d}}\end{array}$ & $\begin{array}{l}\text { - } \text { strengthening and } \\
\text { maintaining the position of } \\
\text { the Russian Federation in the } \\
\text { global energy sector, at least } \\
\text { for the period up to } 2035\end{array}$ \\
\hline
\end{tabular}

Source: Author's compilation

b The Energy strategy of Russia until 2020, adopted by the order of the Government of the Russian Federation from August 28, 2003, № 1234-r.

c The Energy strategy of Russia until 2025, adopted by the order of the Government of the Russian Federation from November 13, 2009,. №1715-r.

d The Energy strategy of Russia until 2035, adopted by the order of the Government of the Russian Federation from June 9, 2020, № 1523-r.
Table 2. Energy strategy targets: the role of the Far East.

\begin{tabular}{|c|c|c|}
\hline $\begin{array}{l}\text { Energy } \\
\text { strategy }\end{array}$ & $\begin{array}{l}\text { The share of } \\
\text { Asia-Pacific } \\
\text { countries in } \\
\text { the } \\
\text { geographical } \\
\text { structure of } \\
\text { exports, \% }\end{array}$ & $\begin{array}{l}\text { The share of production } \\
\text { in Eastern Siberia and the } \\
\text { Russian Far East in the } \\
\text { total volume of } \\
\text { production in Russia, \% }\end{array}$ \\
\hline $\begin{array}{l}\text { Energy } \\
\text { strategy } \\
-2020\end{array}$ & $\begin{array}{l}\text { Oil -30\% } \\
\text { Natural gas - } \\
15 \%\end{array}$ & $\begin{array}{l}\text { Oil 6-8 }(2010) ; 16- \\
20(2020) \\
\text { Natural gas 5-8 (2010); } \\
14-15(2020) \\
\text { Coal 22-25 (2010); } \\
22-24(2020)\end{array}$ \\
\hline $\begin{array}{l}\text { Energy } \\
\text { strategy } \\
-2030\end{array}$ & $\begin{array}{l}\text { Oil and } \\
\text { petroleum } \\
\text { products } \\
22-25 \% \\
\text { Natural gas - } \\
19-20 \%\end{array}$ & $\begin{array}{l}\text { Oil } 10-12 \quad(2015) ; 12- \\
14(2022) ; 18-19(2030) \\
\text { Natural gas } 7-8 \quad(2015) ; \\
12-14(2022) ; 15(2030) \\
\text { Coal } 38-39 \quad(2015) ; \\
41-42 \quad(2022) ; \\
47(2030)\end{array}$ \\
\hline $\begin{array}{l}\text { Energy } \\
\text { strategy } \\
-2035\end{array}$ & $\begin{array}{l}\text { In total } \\
\text { energy } \\
\text { export - } \\
50 \% \text {. }\end{array}$ & $\begin{array}{l}\text { Oil } 14 \text { (2024);15- } \\
17(2035) \\
\text { Natural gas } 17 \text { (2024); } \\
\text { 23(2035) } \\
\text { Coal 43 (2024); } \\
\text { 48(2035) }\end{array}$ \\
\hline
\end{tabular}

Source: Author's compilation

Table 3. Planned projects in the Energy Strategy and realized large sale energy projects in Russian Far East in 2003-2020

\begin{tabular}{|c|c|}
\hline Planned projects & Realized projects \\
\hline \multicolumn{2}{|c|}{ Energy strategy -2020} \\
\hline $\begin{array}{l}\text { - Creation of new } \\
\text { oil production } \\
\text { centers in the east } \\
\text { territories of the } \\
\text { country (Eastern } \\
\text { Siberia, the } \\
\text { Republic of Sakha } \\
\text { (Yakutia), the } \\
\text { shelf of Sakhalin } \\
\text { Island); } \\
\text { Pipeline Angarsk- } \\
\text { Nakhodka (80 } \\
\text { million tons per } \\
\text { year) with a } \\
\text { branch to China }\end{array}$ & 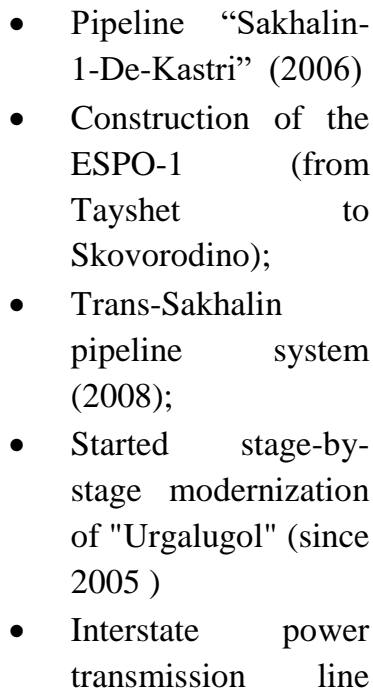 \\
\hline
\end{tabular}




\begin{tabular}{|c|c|}
\hline $\begin{array}{l}\text { (Daqing); } \\
\text { Oil and gas } \\
\text { pipelines for } \\
\text { projects Sakhalin- } \\
1^{\prime \prime} \text { и " Sakhalin- } \\
2 \text { "; } \\
\text { Development of } \\
\text { new large gas } \\
\text { producing centers } \\
\text { in Eastern Siberia } \\
\text { and the Russian } \\
\text { Far East, on the } \\
\text { Yamal Peninsula } \\
\text { and on the shelves } \\
\text { of the Arctic and } \\
\text { Far Eastern seas; } \\
\text { Upgrading and } \\
\text { increasing the } \\
\text { capacity of ports } \\
\text { such as Vostochny } \\
\text { and Vanino. }\end{array}$ & $\begin{array}{l}\text { Sirius } \\
\text { Blagoveshchenskaya } \\
(220 \mathrm{kV} ; 2006) .\end{array}$ \\
\hline \multicolumn{2}{|c|}{ Energy strategy -2030} \\
\hline $\begin{array}{l}\text { Oil pipeline } \\
\text { Eastern Siberia - } \\
\text { Pacific Ocean } \\
\text { Primorsky Oil } \\
\text { Refinery - 20 } \\
\text { million tons per } \\
\text { year } \\
\text { New gas } \\
\text { production } \\
\text { centers: Sakhalin } \\
\text { and Yakutia } \\
\text { Coal mining in } \\
\text { new fields in } \\
\text { Eastern Siberia } \\
\text { and the Far East } \\
\text { (Urgalskoye, } \\
\text { Elegestskoye, } \\
\text { Elginskoye, } \\
\text { Apsatskoye) } \\
\text { - Modernizat } \\
\text { ion of oil loading } \\
\text { terminals in } \\
\text { Nakhodka, De- } \\
\text { Kastri, and coal- } \\
\text { fired - in the ports } \\
\text { of Vanino and } \\
\text { Vostochny }\end{array}$ & 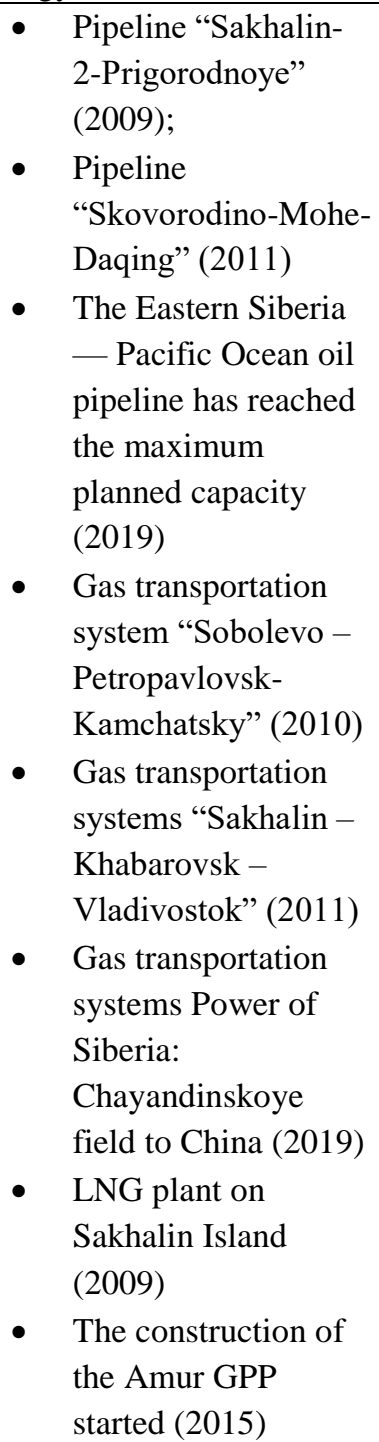 \\
\hline
\end{tabular}

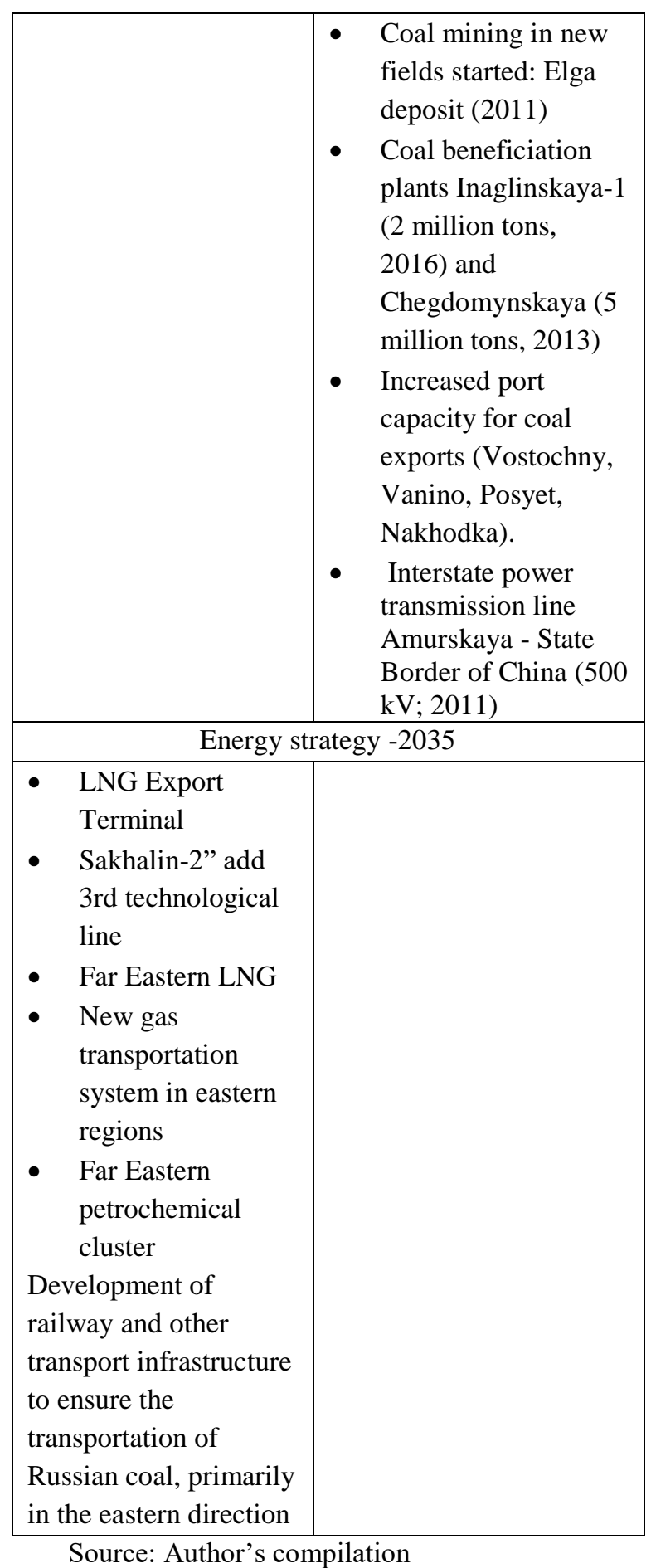

Strategic priorities for the development of the fuel and energy sectors of the Far East in the period up to 2035 remain the same: the dominance of national interests of foreign energy policy aimed at further increasing the share of Russian energy exports in the Asia-Pacific markets, which requires a corresponding increase in energy production and the expansion of transport infrastructure in the Far East. The main effects of these projects will be consolidated at the federal budget level. The planned creation of gas processing and gas chemical production facilities in the region, since it is implemented on imported equipment and is focused on the export of products, will not be able to serve as an impulse to stimulate the development of the territories of 
the Far East $[5 ; 6]$. In the current system of distribution of export revenues, tax payments and with this organizational structure of the complex industries, the accelerated development of the eastern regions of the country due to the intensification of the development of the fuel and energy sectors of these territories looks problematic.

\section{References}

1. Bushuev V.V., Gromov A.I., Kurichev N. K. Energy strategy-2050: methodology, challenges, opportunities. ESCO Energy and industry. No. 6. Pp. 14-19. (2013).

2. Gimadi V. et al. Energy Strategy in the Era of Change. Energy Bulletin. Issue 85. 29 p. (2020).

3. Dyomina O.V. World Hydrocarbon Markets: Effective Strategies of Players. Prostranstvennaya Ekonomika [Spatial Economics]. No. 3. P p. $67-$ 87. (2018).

4. Dyomina O.V., Ognev A.Y. The Development of Energy Cooperation between Russia and China: The Declaration and Practice. In: Energy of Russia in XXI Century. Innovative Development and Management. Irkutsk. Pp. 141-147. (2015).

5. Dzhurka, N. G. Dyomina, O. V. Evaluating the Consequences of the Gas Processing Complex Creation in the Russian Far East. [Economy of Region]. No. 14(2). P p. 450-462. (2018).

6. Dzhurka N.G., Dyomina O.V. Evaluating Impacts of the New Industry on the Regional Economy: Petrochemistry in the Far East. Prostranstvennaya Ekonomika $=$ Spatial Economics, vol. 16, no. 1, pp. 51-65. (2020).

7. Mastepanov A. The Diversification of Russian Gas Exports and East Energy Policy of Russian Federation // The Energy Policy. No.3. (2014).

8. Minakir Pavel A. Regions' Economics. Russian Far East / edited by A.G. Granberg; Rus. Acad. Sci., Far East. Branch, Economic Research Institute. M.: Economica. 848 p. (2006).

9. Saneev B. G. Eastern energy policy of Russia: directions, approaches of science and practice to its implementation // Region: Economics and Sociology. 2007. No. 1. pp. 298-305. (In Russian).

10. Fang Tingting The Development of Sino-Russian Energy Cooperation. Russia and the Pacific. No. 1 (75). Pp. 96-103. (2012). 